\title{
Organizational Complexity and Succession Planning
}

\author{
Lalitha Naveen*
}

\begin{abstract}
This study uses a large sample of firms to examine how human capital considerations affect the process of CEO succession. Costs and benefits of succession planning are affected by a firm's level of operational complexity and human capital requirements; firms that are more complex incur greater costs to transferring firm-specific knowledge and expertise to an outsider, and should be more likely to groom an internal candidate for the CEO position. Consistent with this, I find that a firm's propensity to groom an internal candidate for the CEO position is related to firm size, degree of diversification, and industry structure. My results also suggest that succession planning is associated with a higher probability of inside succession and voluntary succession and a lower probability of forced succession. I also provide evidence that horizon problems are mitigated to some extent by having a succession plan.
\end{abstract}

\section{Introduction}

Highly publicized CEO transitions at large firms such as AT\&T and GE have captured the attention of academic scholars and the business media and, at the same time, have highlighted the importance of CEO succession. Thus, it is quite natural that some company boards demonstrate a strong interest in identifying and installing the right individual to replace the outgoing CEO. At Ralston Purina, for instance, CEO William Stiritz was awarded options estimated to be worth more than $\$ 16$ million contingent on his finding a suitable successor. At Abbott Labs, the board of directors ousted chairman and CEO Robert Schoellhorn after he fired

${ }^{*}$ Naveen, lalitha@gsu.edu, Department of Finance, J. Mack Robinson School of Business, Georgia State University, 35 Broad Street, Atlanta, GA 30303. I am grateful to Jeff Coles and Mike Lemmon for providing valuable encouragement and advice. The paper has benefited greatly from their input. I thank David Yermack (associate editor and referee) for suggestions that have significantly improved the paper. For helpful comments, I thank James Booth, Murillo Campello, Dan Deli, Michael Hertzel, Jayant Kale, Jonathan Karpoff (the editor), William Greene, Omesh Kini, Jim Linck, Robert Parrino, Tod Perry, Mike Rebello, Steve Smith, Kumar Venkataraman, and, especially, Naveen Daniel. Finally, I am grateful to seminar participants at Arizona State University, Babson College, Columbia University, the FMA Doctoral Student Symposium, the 2000 FMA Meeting, Georgia State University, Miami University, New York University, University of Missouri-Columbia, and Virginia Tech for several helpful suggestions. Earlier versions of this paper were entitled "Management Turnover and Succession Planning in Firms." 
three successive presidents, all of whom were considered to be his potential successors. According to Spencer Stuart, an executive search firm, boards are tying as much as one-third of the CEO's bonus to the development of accession plan. CEO succession appears to be an important concern for the coiporation, its shareholders, and its employees.

Nevertheless, CEO succession as a process has received little explicit attention in the finance literature. Instead, most contributions address the individual components of CEO transitions such as the determinants of CEO turnover, the choice between an inside and an outside successor, and the practice of combining the CEO and chairman positions. ${ }^{1}$ Little research, however, has been devoted to studying how these various components are part of any sort of delibe;rate process guiding CEO succession. This paper is a step toward understanding this important decision. Using a large sample of firms, I examine how human capitall considerations affect the process of CEO succession in firms.

The only work to this point focused directly on CEO succession is Vancil (1987), who bases his main conclusions on a small number of case studies. Vancil suggests that one common pattern of succession is "relay succession." This process includes the selection of an heir apparent a few years before the CEO is expected to step down. The heir apparent and the incumbent CEO then work together until the latter steps down (usually to become chairman of the board) and the heir apparent takes over. In my study, I identify a firm as having an heir apparent and, therefore, a relay succession if the firm has a president or chief operating officer (COO) distinct from the CEO or chairman. ${ }^{2} \mathrm{My}$ analysis reveals several interesting findings.

First, I find that the relay process for CEO succession, as represented by Vancil (1987), is used by a significant proportion of sample firms. Many firms in my sample appear to plan for succession by designating a successor in anticipation of CEO turnover. For instance, four years before CEO turnover, $41 \%$ of firms have an heir apparent. Immediately before turnover, this number jumps to $60 \%$. Because the relay model of succession appears to be common, the remainder of this analysis focuses on relay succession. To be sure, some firms rely on some other sort of process at the CEO level. Therefore, as a basis of comparison, I use a complementary subsample of firms including firms that use the horse race model exemplified by GE, firms with other, less well-defined processes, and firms with no process at all.

Second, I find that relay succession is more likely in larger firms, more diversified firms, and in certain industries where human capital is less easily transferable across firms. In general, this set of results is consistent with simple notions of how operational complexity and human capital are likely to affect the benefits versus costs of using the relay succession process. Several hypotheses are detailed in Section II, but the general idea is as follows. Firm-specific human capital

\footnotetext{
'See, for example, Warner, Watts, and Wruck (1988), Weisbach (1988), Agrawal, Knoeber, and Tsoulouhas (2006), Cannella and Lubatkin (1993), Borokhovich, Parrino, and Trapani (1997), Parrino (1997), Brickley, Coles, and Jarrell (1997), and Baliga, Moyer, and Rao (1996).

${ }^{2}$ For example, Vancil (1987), Cannella and Lubatkin (1993), and Dechow and Sloan (1991) suggest that the president is the most likely person to become the next CEO. This is also supported strongly by anecdotal evidence (see the Appendix, which is available from the author, for some examples). I also use other proxies for this measure that I discuss in Section V.B.
} 
includes "expertise about a firm's products, customers, competitors, and employees, as well as an informal network of people providing information and support" (Bonnier and Bruner (1989), p. 100). Also, in more complex firms the CEO needs a deep understanding of the geographical and product markets in which the firm competes and the synergies among the firm's various divisions. In many cases, it is likely that much of this expertise and knowledge base is applicable primarily to that one firm. Further, it may be expensive to transfer knowledge and expertise to an incoming outsider. Such firms, therefore, are likely to prefer a new CEO from within the company who already has the relevant firm-specific human capital. This is reinforced by the likelihood that the very existence of a relay succession process and the higher probability of promoting from within amplifies the incentives for managers to invest in such firm-specific human capital (Carmichael (1983)). Therefore, to the extent that size, diversity of operations, and industry classification are correlated with operational complexity, human capital specificity, and costs of transferring knowledge and expertise, these measures should be associated with the propensity to use relay succession for the CEO position.

Third, I find that succession planning affects the choice of CEO turnover. Specifically, I find that succession planning is associated with a higher probability of inside and voluntary succession and a lower probability of outside and forced succession. This is consistent with the notion that planning reduces the costs of CEO succession and ensures a more orderly transition from one CEO to the next.

I find little evidence that succession planning is associated with managerial entrenchment. Abnormal returns on the announcement of the appointment of a president are on average significantly positive. Also the market-to-book ratio is similar for firms with and without relay succession plans. Further, the probability that the designated successor becomes the next CEO appears to depend on stock price performance in the year prior to CEO turnover.

Finally, I find some evidence that relay succession helps to mitigate the horizon problems documented in the literature (Dechow and Sloan (1991), Murphy and Zimmerman (1993)). I find that investments in R\&D decrease with CEO tenure, but this effect is lower for firms with relay succession. Also, earnings management increases with CEO tenure, but this effect is lower for firms with relay succession.

The remainder of the paper is organized as follows. Section II discusses costs and benefits of relay succession and develops testable hypotheses. Section III describes the data. Section IV (Section V) presents univariate (multivariate) results on my main hypotheses. Section VI discusses alternative interpretations of the results and robustness. Section VII concludes.

\section{Hypotheses Development}

\section{A. The Relay Succession Plan versus Other Succession Plans}

One way in which an organization can ensure that the new CEO possesses all the skills required is to have a formal succession process, such as relay succession. In a relay succession, an heir apparent is selected a few years before the incumbent $\mathrm{CEO}$ retires. The heir then works with the incumbent $\mathrm{CEO}$ gaining valuable 
human capital until he is designated as the new CEO. Typically, the incumbent CEO remains as chairman of the firm for one or two years, giving the successor time to make the transition from heir apparent to CEO. The new CEO typically retains the president post until he is ready to select the next heir apparent.

Certainly, there are other kinds of succession processes. One example is the horse race, where two or more top executives compete for the CEO post. Firms could also have a more ad hoc type of succession plan. An extreme example is the Ben \& Jerry succession plan, where the firm launched an essay contest to find a successor for CEO Ben Cohen. ${ }^{3}$ Finally, a firm could have no succession plan at all, in which case there is no clearly identified successor before the CEO turnover, and the firm initiates the search for the successor after the CEO turnover.

In this study, I examine briefly (in Section VI.D) the characteristics of firms that have horse race succession, and contrast them with firms that have relay succession. For the most part, however, I focus on relay succession. All other firms, including firms using horse race successions, firms using ad hoc succession plans, and firms that have no obvious succession process are grouped together. The reason for grouping all other firms together is that it is hard to differentiate between firms that have horse race successions as a formal succession mechanism and firms that have more ad hoc succession mechanisms or no formal succession mechanisms. This grouping, however, is not a significant concern for two reasons. First, Vancil (1987) and Brickley et al. (1997) find that relay succession is by far the most common type of succession process. Consistent with this, I find that the majority of firms in my sample adopt the relay succession process. Second, the inability to differentiate between firms that have horse race or ad hoc succession plans and firms that have no succession plans merely introduces noise into my measure for succession planning and reduces the power of my tests to detect differences between firms with relay succession and all others!

It should be noted, however, that firms may be in different phases of the succession process. This could result in a firm being classified as not having a succession plan in a particular year, even if the firm in general has one. To address this concern, I redefine a firm as having a succession plan over the sample period if it had a succession plan in any of the individual years. The main results are largely robust to this alternative definition of succession planning. A more detailed discussion is presented in Section VI.A.

\section{B. Organizational Complexity, Human Capital Specificity, and Succession Costs}

An important consideration in the selection of a CEO is the amount of human capital possessed by candidates for the position (Parrino (1997)) because there is significant potential for costly errors and missed opportunities during the period that it takes a new CEO to acquire the necessary human capital. Succession costs include any costs resulting from these errors and lost opportunities; the more time it takes the CEO to settle down in the job, the greater the potential succession

\footnotetext{
${ }^{3}$ The Wall Street Journal, "Ben \& Jerry's scoffs at tradition, hires some suits tó find a CEO," Aug. 10, 1994. The Wall Street Journal, "Ben \& Jerry's is looking for Ben's successor," June 14, 1994.
} 
costs. This consideration would affect the choice between hiring a CEO from inside the firm and hiring one from outside the firm. Therefore, one way in which firms can lower expected succession costs is to select and train a suitable in-house successor. The greater the operational complexity of the firm, the greater will be the expected succession costs associated with an outside successor, and the more likely the firm will be to have a relay succession plan.

An added benefit to such firms from choosing an insider is that internal promotion encourages managers to invest in firm-specific human capital (Becker (1964), Chan (1996), and Jaggia and Thakor (1994)). In contrast, more outside appointments could cause insiders to revise downward their expected probability of making it to the top, and could result in lower incentives to perform (Lazear and Rosen (1981)). Furtado and Rozeff (1987) suggest that firms may prefer insiders as they could earn returns on the firm-specific human capital of insiders. ${ }^{4}$

\section{Factors Affecting Relay Succession Planning}

Based on the above discussion, several testable hypotheses follow. First, to the extent that size is correlated with organizational complexity, I expect that larger firms would be more likely to have succession plans. Larger firms are likely to be more complex (Reinganum (1985)) and to rely more on internal capital markets (Furtado and Rozeff (1987)). Himmelberg and Hubbard (2000) argue that the supply of CEOs who possess the skill to manage large firms is limited. Parrino (1997) conjectures that formal succession processes are more likely to be found in larger than in smaller firms. ${ }^{5}$

H1. Relay succession planning is more likely in larger firms, all else equal.

Second, Parrino (1997) argues that outside succession is more likely in homogeneous industries (industries comprised of firms with relatively similar tech-

\footnotetext{
${ }^{4}$ Using a relay succession plan can also potentially impose costs. Firms that decide not to promote the heir apparent as CEO could incur an implicit cost, namely, the loss in credibility of the firm's succession policy. This would lower the incentives of executives to exert effort and to invest in firmspecific human capital ex ante. Since firms that do not value firm-specific human capital are more likely to do this, these firms cannot credibly commit to implementing a succession plan. There also are explicit costs in the form of any severance pay, which could be substantial. For example, Michael Ovitz collected a severance package of nearly $\$ 95$ million when he resigned as president of Disney. John Walter, president of AT\&T, resigned nine months after joining when he learned that he would not be considered for the CEO post. His total remuneration, including severance pay was about $\$ 30$ million for the nine-month period. At TRW, the president, David Cote, was guaranteed payment of $\$ 10$ million if he did not become CEO within a stipulated time.

${ }^{5}$ It could perhaps be argued that CEOs of large firms need more human capital, but not necessarily firm-specific human capital. For example, the CEO of a large firm may only be responsible for high level planning, whereas the CEO of a small firm may also be responsible for day to day operations. To be successful in any firm, however, the CEO needs some amount of firm-specific human capital including knowledge of the firm's strategy, customers, competitors, and a relationship with key employees and board members. The time it takes an outsider to acquire such firm-specific knowledge increases with firm size; succession costs, therefore, also increase with firm size. Therefore, all else equal, larger firms will find it more costly to bring in outside candidates. For instance, H. Lee Scott, CEO of Wal-Mart, states that exposing the heir apparent and other high level executives to many different aspects of the business and developing their relationship with the board are critical for a smooth CEO transition (The Wall Street Journal, "Boss Talk: How Wal-Mart transfers power," March 27, 2001). Similarly, it has been argued that Rick Thoman, who was hired from IBM as CEO of Xerox, failed in part because he lacked sufficient knowledge about the firm and the firm's key executives including the board members.
} 
nologies and product markets) for two reasons. First, in such industries, relative performance measures provide more precise performance signals, making it easier to evaluate outside candidates. Second, the value of specific human capital possessed by internal candidates is likely to be lower in such industries as more of their skills are portable. Succession planning should thus be less likely in homogeneous industries. In contrast, in heterogeneous industries firms within the industry are less similar, and firm-specific human capital is transferable to a smaller extent. Succession planning, therefore, should be more likely in these industries.

H2. Relay succession planning is more likely in heterogeneous industries, all else equal.

Third, firms that have more complex organization, such as diversified firms, are more likely to require a high level of firm-specific human capital. Diversification may increase the complexity of the CEO's job. Resource allocation decisions become more complex (Finkelstein and Hambrick (1989)). Also, the CEO has to understand several potentially disparate product markets and therefore needs greater ability (Rose and Shepard (1997)). Diversified firms should thus be more likely to appoint an insider as the CEO and to engage in succession planning.

H3. Relay succession planning is more likely in diversified firms, all else equal.

\section{Succession Planning and Type of Turnover}

Given my earlier characterization of relay succession, two hypotheses follow regarding the nature of the succession process. First, if firms do relay succession planning to reduce expected costs of succession then such firms should also be more likely to appoint an insider as the new CEO. Specifically, the heir apparent should be appointed as the new CEO. At first glance, this may seem almost a mechanical effect. First, I code firms as having relay succession if they have a president, and then I argue that these firms are more likely to appoint the president as the CEO. For this hypothesis to be true, however, Vancil's (1987) depiction of the president as the designated successor in a relay succession has to be correct. If this were not true, firms that I code as having a relay succession should be just as likely to appoint some insider (other than the president) or even an outsider as the next CEO.

H4. Firms that do relay succession planning are more likely to have an inside successor (specifically the heir apparent), all else equal.

Second, if one of the reasons for succession planning is to ensure an orderly transition, then succession planning is more likely to be associated with normal rather than forced succession. Indeed, as the earlier example of Abbott Labs illustrates, the absence of succession planning may itself be reason to force turnover of the incumbent CEO. This implies that the probability of forced turnover is lower in firms with relay succession plans.

H5. The probability of forced turnover is expected to be lower for firms that do relay succession planning, all else equal. 


\section{Data}

My starting sample comprises firms included in the Forbes 1991 Compensation Surveys, which also have data available on CRSP and COMPUSTAT. Details of the CEO name, age, tenure, and ownership are taken from Forbes for the years 1987-1997. If the firm is not listed in Forbes surveys in subsequent years, details are obtained through Lexis/Nexis.

An indicator variable, TURNOVER, is set equal to 0 for 1987 and 1 every time the CEO changes thereafter. Turnovers due to mergers are excluded from the sample ( $<5 \%$ of observations). Interim successions (where the CEOs are nominated in an interim capacity and hold office for less than a year) are not considered as turnovers. I identify forced departures similar to Parrino (1997). I include all CEO departures that are reported as forced. Also, a departure is identified as forced when the CEO is under 60 and leaves for reasons unrelated to death, illness, or acceptance of any position within or outside the firm. Turnover announcements are obtained from the Dow Jones News Service.

A firm is defined as having a relay succession plan for a given year if it has a president or $\mathrm{COO}$ who is distinct from the $\mathrm{CEO} /$ chairman and is not older than the CEO/chairman (my results hold even if I do not impose this age restriction). This information is obtained from Compact Disclosure and Lexis/Nexis proxy statements. The final sample consists of 6,714 firm-years with information on stock returns, book value of assets, and succession planning.

\section{Discussion of Univariate Results}

\section{A. Sample Characteristics}

Table 1 indicates that of the 691 turnovers, 102 are forced turnovers and 148 involve outside succession. The overall frequency of turnover (10.3\%) and forced turnover (14.8\%) is similar to that in Parrino (1997) and Huson, Parrino, and Starks (2001). The percentage of turnovers with outside succession is $21.4 \%$, slightly higher than Parrino's sample (15\%) and the Huson et al. (2001) sample (19\%). The difference could be due to the higher outside succession rate over the last three years of my sample-the average outside succession rate is $25 \%$ over the period 1995-1997 compared to $19 \%$ for the period up to 1994. The last two columns in Table 1 indicate the number and percentage of turnovers in firms that had an heir apparent; 422 of the 691 turnovers (over 60\%) are in firms that had an heir apparent before the turnover.

\section{B. Univariate Results}

Table 2 reports statistics on firm characteristics, CEO turnover, and outside succession. Firms with relay succession tend to be larger ( $\$ 4.8$ billion assets versus $\$ 4$ billion) and more diversified (Herfindahl index of 0.70 versus 0.72 ). These differences are statistically significant at the $1 \%$ level, consistent with hypotheses $\mathrm{H} 1$ and $\mathrm{H} 3$. Consistent with the hypothesis that firms with relay succession should have greater inside succession (H4), the frequency of outside succession is significantly lower for these firms $(6.6 \%$ versus $44.6 \%)$. Also, the frequency 


\section{TABLE 1}

\section{Descriptive Details of CEO Turnover, Forced Turnover, and Outside Succession}

\begin{tabular}{|c|c|c|c|c|c|c|c|c|}
\hline $\begin{array}{l}\text { The sa } \\
1997 \text { y } \\
\text { on aco } \\
\text { If The } \\
\text { to hea } \\
\text { takes } \\
\text { presid }\end{array}$ & $\begin{array}{l}\text { e is drawn } \\
91 \text { turnov } \\
t \text { of merge } \\
\text { Street Jo } \\
\text { easons or } \\
\text { alue } 1 \text { if th } \\
\text { coo not } 0\end{array}$ & $\begin{array}{l}m \text { the } \\
\text { Turno } \\
\text { re not } \\
\text { a iden } \\
\text { ake up } \\
\text { ew CE } \\
\text { than t }\end{array}$ & $\begin{array}{l}\text { es Annual } \\
\text { s set equal } \\
\text { sidered. Fo } \\
\text { the turno } \\
\text { smparable } \\
\text { as been wi } \\
\text { EO or cha }\end{array}$ & $\begin{array}{l}\text { pensation S } \\
\text { every time } \\
d \text { is a dumm } \\
\text { as forced or } \\
\text { ition in anot } \\
\text { e firm for a } \\
\text { in. }\end{array}$ & $\begin{array}{l}\text { ys and c } \\
\text { CEO chan } \\
\text { at takes th } \\
\text { e CEO is } \\
\text { firm, then } \\
\text { or less. }\end{array}$ & $\begin{array}{l}\text { Is of } 6,714 \\
\text { Interim CE } \\
\text { lue } 1 \text { for for } \\
\text { than } 60 \text { ye } \\
\text { lurnover is } \\
\text { apparent is }\end{array}$ & $\begin{array}{l}\text { years of o } \\
\text { anges anc } \\
\text { urnoyers, } \\
\text { and does } \\
\text { ified as fo } \\
\text { qual to } 1\end{array}$ & $\begin{array}{l}\text { rom } 1988- \\
\text { changes } \\
\text { voluntary. } \\
\text { esign due } \\
\text { l. Outsider } \\
\text { firm has a }\end{array}$ \\
\hline & Turne & & & & & $\begin{array}{l}\text { de } \\
\text { sions }\end{array}$ & $\mathrm{A}$ & \\
\hline Year & Number & $\%$ & Number & $\begin{array}{l}\% \text { of Total } \\
\text { Turnovers }\end{array}$ & Number & $\begin{array}{l}\% \text { of Total } \\
\text { Turnovers }\end{array}$ & Number & $\begin{array}{l}\% \text { of Total } \\
\text { Turnovers }\end{array}$ \\
\hline 1988 & 60 & 8.7 & 4 & 6.7 & 10 & 16.7 & 42 & 70.0 \\
\hline 1989 & 62 & 8.8 & 7 & 11.3 & 11 & 17.7 & 42 & 67.7 \\
\hline 1990 & 83 & 11.6 & 10 & 12.0 & 12 & 14.5 & 57 & 68.7 \\
\hline 1991 & 73 & 10.3 & 17 & 23.3 & 21 & 28.8 & 41 & 56.2 \\
\hline 1992 & 63 & 8.9 & 11 & 17.5 & 11 & 17.5 & 39 & 61.9 \\
\hline 1993 & 77 & 11.2 & 10 & 13.0 & 18 & 23.4 & 45 & 58.4 \\
\hline 1994 & 69 & 10.3 & 6 & 8.7 & 12 & 17.4 & 48 & 69.6 \\
\hline 1995 & 84 & 13.2 & 17 & 20.2 & 24 & 28.6 & 44 & 52.4 \\
\hline 1996 & 58 & 9.5 & 9 & 15.5 & 14 & 24.1 & 33 & 56.9 \\
\hline 1997 & 62 & 10.8 & 11 & 17.7 & 15 & 24.2 & 31 & 50.0 \\
\hline All & 691 & 10.3 & 102 & 14.8 & 148 & 21.4 & 422 & 61.1 \\
\hline
\end{tabular}

of forced turnover is significantly lower (5.7\% versus $29 \%$ ). This is consistent with hypothesis (H5). Another explanation for this finding is that CEOs of firms that are likely to have normal rather than forced successions are more likely to nominate an heir. A poorly performing CEO may want to keep replacement costs high and may not have an incentive to nominate a successor.

Panel B shows that new CEOs in firms that have (do not have) an heir apparent spend on average about 19 years (11 years) in the firm before becoming CEO. To the extent that the number of years spent in the firm proxies for firm-specific human capital, this finding is consistent with firms with relay succession requiring more firm-specific human capital.

Figure 1 presents large sample confirmation of Vancil's (1987) description of the relay succession process. The first series in the figure represents the proportion of firms whose CEOs have the combined title of chairman and CEO. The second series represents the proportion of firms that have an heir apparent. Immediately before the turnover year, $78 \%$ of firms have CEOs with the combined title and $60 \%$ of firms have an heir apparent, which is consistent with Brickley et al. (1997) who find that $80 \%$ of their sample firms have CEOs with the dual title of $\mathrm{CEO}$ and chairman. Immediately following the succession, the proportion of firms having CEOs with combined titles falls to $55 \%$, as the chairman and CEO transfers the title of CEO to the successor. In some cases, chairman and CEO titles are simultaneously transferred. The proportion of firms with an heir apparent also falls to $19 \%$ after the succession as the new CEO needs time to evaluate candidates and nominate his successor.

Table 3 shows the designations of the incumbent CEOs and their successors. For the full sample of successions, 399 successors (58\%) were president and/or $\mathrm{COO}$ of their firms at the time they were appointed CEO. Less than $3 \%$ were chairmen of their firms, $6.4 \%$ were vice chairmen, and about $18 \%$ were from outside the firm. In the relay succession group, as expected presidents/COOs 


\section{TABLE 2}

\section{Association between Relay Succession Planning and CEO Characteristics, Firm Characteristics, and Turnover Characteristics}

The sample is drawn from the Forbes Annual Compensation Surveys and consists of 6,714 firm-years of data from 1988 1997 with 691 turnovers. Turnover is set equal to 1 every time the CEO changes. Interim CEO changes and CEO changes on account of mergers are not considered. Forced is a dummy that takes the value 1 for forced turnovers, 0 for voluntary. If The Wall Street Journal identifies the turnover as forced or if the CEO is less than 60 years and does not resign due to health reasons or to take up a comparable position in another firm, then the turnover is classified as forced. Outsider takes the value 1 if the new CEO has been with the firm for a year or less. Heir apparent is set equal to 1 if the firm has a president/COO not older than the CEO or chairman. The Herfindaht index measures the level of firm diversification and is calculated as $\sum s_{i}^{2} /\left(\sum s_{i}\right)^{2}$, where $s_{j}$ is the sales of segment $i$. For single segment firms, the Herfindahl index is 1 and for multi-segment firms, it is less than 1 . Adjusted return is the return in excess of the CRSP value-weighted market return. Adjusted ROA is the return on assets, defined as operating profits over assets, in excess of the four-digit industry median All figures given are mean values. ${ }^{a} p$-value for tests of difference in means (difference in proportions where applicable) between heir apparent and no heir apparent firms.

\begin{tabular}{|c|c|c|c|c|}
\hline & All Firms & Apparent & $\begin{array}{c}\text { Heir } \\
\text { Apparent }\end{array}$ & $\begin{array}{l}\text { No Heir } \\
p \text {-Value }\end{array}$ \\
\hline \multicolumn{5}{|c|}{ Panel A. Details of CEO Turnover, Firm Size, and Performance } \\
\hline No. of observations & 6,714 & 2,521 & 4,193 & \\
\hline No. of turnovers & 691 & 422 & 269 & \\
\hline No. of outside successions & 148 & 28 & 120 & \\
\hline No. of forced turnovers & 102 & 24 & 78 & \\
\hline Frequency of turnover & $10.3 \%$ & $16.7 \%$ & $6.4 \%$ & 0.00 \\
\hline Outside successions as \% of total successions & $21.4 \%$ & $6.6 \%$ & $44.6 \%$ & 0.00 \\
\hline Forced turnovers as $\%$ of total turnovers & $14.8 \%$ & $5.7 \%$ & $29.0 \%$ & 0.00 \\
\hline Book value of assets ( $\$$ million) & 4,311 & 4,757 & 4,064 & 0.00 \\
\hline Herfindahl index & 0.71 & 0.70 & 0.72 & 0.01 \\
\hline Lagged adjusted returns (\%) & 2.10 & 1.47 & 2.48 & 0.23 \\
\hline Lagged adjusted ROA (\%) & 3.57 & 3.43 & 3.66 & 0.30 \\
\hline \multicolumn{5}{|l|}{ Panel B. Details of Incoming and Departing CEO } \\
\hline \multicolumn{5}{|l|}{ Departing CEO } \\
\hline Age & 61.3 & 62.3 & 59.8 & 0.00 \\
\hline Tenure in firm & 27.9 & 29.9 & 24.8 & 0.00 \\
\hline Tenure as CEO & 10.2 & 11.1 & 8.8 & 0.00 \\
\hline \multicolumn{5}{|l|}{ Incoming CEO } \\
\hline Age & 53.3 & 53.5 & 53.1 & 0.49 \\
\hline Tenure in firm & 16.5 & 18.9 & 11.3 & 0.00 \\
\hline
\end{tabular}

comprise a significant proportion (91.5\%) of successors. Only about $3 \%$ of the successors are outsiders. In contrast, in the group without relay succession only about $4.8 \%$ of successors were formerly the president and/or COO (these were not classified as heirs apparent as they were older than the incumbent CEO). The higher proportion $(17.5 \%)$ of successors in this group who were formerly the executive VP/senior VP/VP could indicate more horse race kinds of successions in this group. About $41 \%$ of the successors in this group are outsiders, appointed directly as CEO.

In Panel B of Table 3, in the relay succession group the incumbent CEO remains on the board as chairman or as director in about $69 \%$ of the successions. This is consistent with post-retirement board service being used to counter horizon problems (Brickley, Coles, and Linck (1999)). In contrast, for the group with no heir apparent the incumbent remains on the board only about $39 \%$ of the time.

\section{Trends in Relay Succession Planning}

I find that $37.6 \%$ of the firm-years had an heir apparent with the proportion declining from $40.2 \%$ in 1988 to $34.8 \%$ in 1997 . This is consistent with Rajan and Wulf (2004) who document a decrease in the COO position over time in their sample. They propose the managerial entrenchment theory and the empire 


\section{FIGURE 1}

\section{Passing the Baton ...}

The sample is drawn from the Forbes Annual Compensation Surveys and consists of 6.714 firm-years of data from 19881997 with 691 turnovers. Turnover is set equal to 1 every time the CEO changes. Interim CEO changes and CEO changes on account of mergers are not considered. Heir apparent takes the value 1 if the firm has a president/coO who is not older than the chairman and CEO. The first series represents the proportion of observations where the CEO has the dual title of chairman and CEO. The second series represents the proportion of observations that has an heir apparent. The typical relay succession works in this manner: the chairman cum CEO transfers the title of CEO to the presicent; he continues as chairman for the next $1-2$ years.

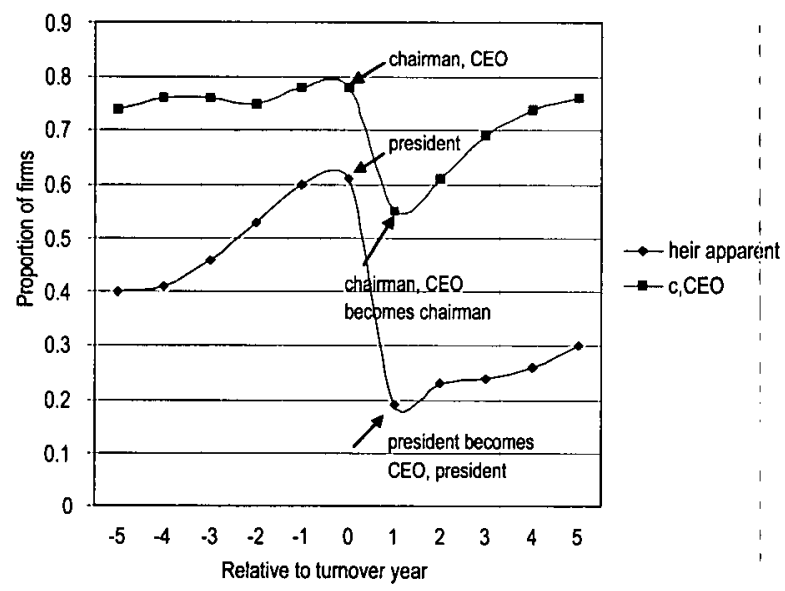

\section{TABLE 3}

\section{Titles of Incumbent CEO and Successor}

The sample is drawn from the Forbes Annual Compensation Surveys and consists of 6,714 firm-years of data from 19881997 with 691 turnovers. Turnover is set equal to 1 every time the CEO changes. Interim CEO change! and CEO changes on account of mergers are not considered. Heir apparent is set equal to 1 if the firm has a president/COO not older than the CEO or chairman. COO indicates chief operating officer, VP indicates vice president. Note that these categories are not mutually exclusive. For instance, the CEO could have formerly been the vice chairman and EVP, in which case he is classified under vice chairman.

\section{Panel A. Incoming CEO}

\begin{tabular}{l} 
Former Designation of CEO \\
\hline President/COO \\
Chairman \\
Vice chairman \\
Executive VP/senior VPNP \\
Outside the firm \\
Other \\
\\
Panel B. Departing CEO \\
$\quad$ CEO Remains as \\
\hline Chairman \\
Director \\
Vice chairman \\
Other \\
No position
\end{tabular}

\section{Full Sample}

\begin{tabular}{|c|c|}
\hline No. of Obs. & $\%$ \\
\hline 399 & 57.7 \\
\hline 18 & 2.6 \\
\hline 44 & 6.4 \\
\hline 51 & 7.4 \\
\hline 124 & 17.9 \\
\hline 55 & 8.0 \\
\hline 691 & 100.0 \\
\hline
\end{tabular}

Full Sample

\begin{tabular}{|c|c|}
\hline No. of Obs. & $\%$ \\
\hline 296 & 42.8 \\
\hline 101 & 14.6 \\
\hline 7 & 1.0 \\
\hline 9 & 1.3 \\
\hline 278 & 40.2 \\
\hline 691 & 100.0 \\
\hline
\end{tabular}

Heir Apparent

\begin{tabular}{|c|c|}
\hline No. of Obs. & $\%$ \\
\hline 386 & 91.5 \\
\hline 0 & 0.0 \\
\hline 7 & 1.7 \\
\hline 4 & 0.9 \\
\hline 13 & 3.1 \\
\hline 12 & 2.8 \\
\hline 422 & 100.0 \\
\hline
\end{tabular}

Heir Apparent

\begin{tabular}{crr}
\hline No. of Obs. & & $\%$ \\
\cline { 1 - 1 } 234 & & 55.5 \\
57 & & 13.5 \\
4 & & 0.9 \\
3 & & 0.7 \\
124 & & 29.4 \\
422 & & 100.0
\end{tabular}

No Heir Apparent

\begin{tabular}{|c|c|}
\hline No. of Obs. & $\%$ \\
\hline $\mid 13$ & 4.8 \\
\hline 118 & 6.7 \\
\hline 36 & 13.4 \\
\hline 47 & 17.5 \\
\hline$\lceil 11$ & 41.3 \\
\hline 44 & 16.3 \\
\hline 69 & 100.0 \\
\hline
\end{tabular}

\begin{tabular}{cr}
\multicolumn{2}{c}{ Nyo Heir Apparent } \\
\hline No. ó Obs. & \multicolumn{1}{c}{$\%$} \\
\cline { 2 - 2 } & \multicolumn{1}{c}{23.0} \\
44 & 16.4 \\
3 & 1.1 \\
6 & 2.2 \\
154 & 57.2 \\
269 & 100.0
\end{tabular}


building theory to explain this decline. The entrenchment theory suggests that CEOs fail to designate potential successors so as to make it harder to replace themselves. Hence, an increase in managerial entrenchment over time could lead to a decrease in the COO position. Rajan and Wulf argue that entrenched CEOs should have a longer tenure. I find that CEOs in firms without succession plans have significantly shorter tenures relative to firms with plans (seven versus 10 years), which is inconsistent with entrenchment.

The empire building theory suggests that CEOs want to build bigger empires by increasing the number of layers in the firm and, therefore, have a $\mathrm{COO}$ position that may not have any power. A decrease in empire building over time could lead to a decrease in the COO position. Rajan and Wulf (2004) suggest that firms in which the CEOs are empire builders should be associated with a lower market-to-book ratio. I find that, controlling for firm size, ownership, and accounting performance (see McConnell and Servaes (1990) and Morck, Shleifer, and Vishny (1988)), the market-to-book ratio does not differ significantly across firms with and without succession plans. This is inconsistent with the empire building hypothesis.

I also consider other explanations for the downward trend in succession planning. First, I consider whether the decrease in relay succession over time could be attributed to a greater frequency of forced turnovers as the CEO could be forced out before an heir is designated. I find, however, that while the frequency of forced turnovers is slightly more in the second half of the sample, the difference is statistically insignificant. A second possibility is that CEOs have shorter tenures and retire earlier in the latter half of the sample before they have time to groom an heir. The retirement age and the tenure of retiring CEOs, however, do not change significantly over the time period of the study.

A third possible explanation is that factors that affect succession planning, such as the extent of industry homogeneity or the level of firm diversification, could change over time. To investigate if the degree of industry homogeneity changed over time in my sample, I first classify industries as homogeneous or heterogeneous (based on Parrino (1997)). Industry homogeneity is calculated as the mean partial correlation coefficient on industry returns in a regression of firm returns on market returns and industry returns. It is larger for more homogeneous industries. The overall average and median partial correlation coefficient is 0.35 and the median is 0.32 (compared to 0.30 and 0.28 in Parrino (1997)). I find that the industry homogeneity measure is similar across the first and second half of the sample period, and the difference across the two time periods is statistically insignificant, suggesting that an increase in industry homogeneity cannot be a possible explanation.

I also examine whether the firms in my sample have become less diversified over time. I use the sales-based Herfindahl index to measure the level of firm diversification. This is defined as $\sum s_{i}^{2} /\left(\sum s_{i}\right)^{2}$, where $s_{i}$ is the sales of segment $i$. For single segment firms, the Herfindahl index is 1 and for multi-segment firms it is less than 1 . The value of the Herfindahl index for the sample firms increases marginally - the mean increases from 0.70 to 0.72 (median increases from 0.70 to 0.76) over the two time periods indicating that firms are becoming more focused over time. The increase is statistically significant suggesting that a trend toward 
greater firm focus could explain the decline in relay succession at least at the univariate level. Another potential explanation for the decline could be the increase of outside-dominated boards over time (Huson et al. (2001)). Outside-dominated boards may have better knowledge of outside candidates and would, therefore, be more likely to appoint outside CEOs (Borokhovich et al. (1996)).

Finally, it is possible that a rapidly changing environment makes succession planning less attractive. If the environment is changing rapidly, then the total risk of firms relative to the industry is likely to have increased over the sample period. I use standard deviation of weekly returns in excess of the two-digit SIC average to proxy for risk. While the median risk is economically and statistically similar across the first and second half of the sample period, the mean value is marginally higher. Also, I find that, controlling for firm size, industry homogeneity, and the Herfindahl index, the probability of succession planning decreases as risk increases. This suggests that firms may have moved away from succession planning in response to a changing environment. This is consistent with Hirshleifer and Welch (2002) who observe that the general trend toward hiring more outsiders can in part be related to the reduced value of memory in a more volatile, globalizing environment. ${ }^{6}$

\section{Discussion of Multivariate Results}

\section{A. Determinants of Succession Planning}

Table 4 uses logistic regressions to examine the factors associated with the use of succession planning. The dependent variable takes the value 1 if the firm has relay succession and 0 otherwise. I use year dummies to capture the decline in relay succession over time. The numbers reported represent the marginal effects of the independent variables on the likelihood of having a succession plan. For continuous variables, this is calculated as the change in probability; of relay succession for a unit change in that variable (holding other variables at their means). For a dummy variable, the marginal effect is calculated for a change in that variable from 0 to 1 .

The marginal effect of firm size on succession planning is positive and is significant at the $1 \%$ level in three of the six specifications. In the specifications that

\footnotetext{
${ }^{6} \mathrm{I}$ also consider two additional possibilities. The first is that sample selection bias could account for this effect. I select my sample by starting with all firms covered in the 1991 Forbes surveys and following these firms through to 1997. During this period, some firms may exit the sample due to takeovers or bankruptcy. Presumably, firms that stay on in the sample are larger firms relative to those that get taken over, and should be more likely to have a relay succession plan. Thus, the selection bias would, if anything, work in the opposite direction, and cannot explain the decline in succession planning. Second, it could be that firms use other kinds of succession processes such as horse race successions. To see if this could explain the decline, I break up my sample into two five-year periods. If firms substitute relay succession with other types of successions such as horse race successions, overall inside succession should remain constant with more CEOs being chosen from the ranks of VPs, which is more typical of horse race successions. This, however, is not the case; in results not reported here, the percentage of CEOs who were formerly executive VPs, VPs, or senior VPs actually falls from the first to the second period for firms both with, and without, an heir, apparent. This, together with the increase in percentage of CEOs from outside the firm, suggests that firms are not substituting relay successions with horse race successions, rather they are increasingly taking in more outsiders as CEOs.
} 


\section{TABLE 4}

\section{Logistic Regressions of Determinants of Relay Succession Planning}

The numbers reported represent the marginal effects from logistic regressions of the independent variables on the likelihood of having a succession plan. The marginal effects of continuous variables are calculated for a unit change of that variable, holding other variables at the means. The marginal effects of dummy variables are calculated for a change in the dummy from 0 to 1 , holding other variables at the means. The sample is drawn from the Forbes Annual Compensation Surveys and consists of 6,714 firm years of data from 1988-1997 with 691 turnovers. Heir apparent is set equal to 1 if the firm has a president/COO not older than the CEO or chairman. Independent variables include lagged firm size (log of assets) and lagged adjusted returns. Adjusted returns are returns net of CRSP value-weighted index. Age64.66 is a dummy variable that takes the value 1 if the departing CEO's age is between 64 and 66 . The industry homogeneity measure is based on the methodology of Parrino (1997) and is calculated as the mean partial correlation coefficient for an industry return index in a two-factor model that also includes the market index. It is larger for more homogeneous industries. The industry homogeneity dummy takes the value 1 for industries that are above the mean value of the industry homogeneity measure. The Herfindahl index equals 1 for single segment firms and is less than 1 otherwise. p-values for significance of coefficient estimates are given in parentheses and are based on robust standard errors. ${ }^{a}$ Fewer observations as segment data is not available for some firms.

Dependent Variable is Heir Apparent

\begin{tabular}{|c|c|c|c|c|c|c|}
\hline Independent Variables & Model 1 & Model 2 & Model 3 & Model 4 & Model 5 & Model 6 \\
\hline Firm size & $\begin{array}{c}0.024 \\
(0.000)\end{array}$ & $\begin{array}{c}0.026 \\
(0.000)\end{array}$ & $\begin{array}{c}0.024 \\
(0.000)\end{array}$ & $\begin{array}{c}0.005 \\
(0.372)\end{array}$ & $\begin{array}{c}0.007 \\
(0.216)\end{array}$ & $\begin{array}{c}0.005 \\
(0.325)\end{array}$ \\
\hline Adjusted returns & $\begin{array}{r}-0.024 \\
(0.201)\end{array}$ & $\begin{array}{r}-0.026 \\
(0.165)\end{array}$ & $\begin{array}{r}-0.025 \\
(0.179)\end{array}$ & $\begin{array}{r}-0.041 \\
(0.053)\end{array}$ & $\begin{array}{r}-0.044 \\
(0.042)\end{array}$ & $\begin{array}{r}-0.042 \\
(0.049)\end{array}$ \\
\hline Age64_66 & $\begin{array}{c}0.318 \\
(0.000)\end{array}$ & $\begin{array}{c}0.317 \\
(0.000)\end{array}$ & $\begin{array}{c}0.318 \\
(0.000)\end{array}$ & $\begin{array}{c}0.321 \\
(0.000)\end{array}$ & $\begin{array}{c}0.320 \\
(0.000)\end{array}$ & $\begin{array}{c}0.320 \\
(0.000)\end{array}$ \\
\hline Homogeneity measure & & $\begin{array}{r}-0.251 \\
(0.006)\end{array}$ & & & $\begin{array}{r}-0.206 \\
(0.029)\end{array}$ & \\
\hline Homogeneity dummy & & & $\begin{array}{r}-0.076 \\
(0.002)\end{array}$ & & & $\begin{array}{r}-0.043 \\
(0.097)\end{array}$ \\
\hline Herfindahl index & & & & $\begin{array}{r}-0.058 \\
(0.020)\end{array}$ & $\begin{array}{r}-0.052 \\
(0.035)\end{array}$ & $\begin{array}{r}-0.057 \\
(0.021)\end{array}$ \\
\hline Year dummy variables & Yes & Yes & Yes & Yes & Yes & Yes \\
\hline No. of obs. & 6,714 & 6,714 & 6,714 & $5,362^{a}$ & $5,362^{a}$ & $5,362^{\mathrm{a}}$ \\
\hline Prob $>x^{2}$ & 0.000 & 0.000 & 0.000 & 0.000 & 0.000 & 0.000 \\
\hline
\end{tabular}

include the Herfindahl index, the statistical significance is lower, probably due to the high correlation between size and diversification. This is consistent with bigger firms being more likely to have a succession plan (H1). Also, consistent with succession planning being more likely in firms in heterogeneous industries ( $\mathrm{H} 2)$, the marginal effect of the industry homogeneity measure is significantly negative $(p \leq 0.05)$. Results are similar when I use a homogeneity dummy that takes the value of 1 if the homogeneity measure is greater than the mean value. ${ }^{7}$ Finally, consistent with the hypothesis that diversified firms should be more likely to have a succession plan (H3), the likelihood of succession planning decreases as the Herfindahl index increases $(p \leq 0.05)$. The marginal effects are also significant in economic terms; for instance, a unit increase in the Herfindahl index and homogeneity measure decreases the probability of succession planning $(=0.37$ at the mean of all variables) by 0.05 and 0.25 , respectively. The effect of the age dummy variable is highly significant, both economically and statistically, consistent with my notion that the heir apparent is appointed when the CEO approaches retirement.

\footnotetext{
${ }^{7} \mathrm{I}$ use the homogeneity dummy because the mean value of the homogeneity measure for firms in my sample is 0.26 , which is lower than the mean for the overall CRSP universe $(0.35)$. The standard deviation of the homogeneity measure is also lower for the sample $(0.07$ compared to 0.15 for the CRSP universe). Given that firms in my sample appear less homogeneous than the overall CRSP average, a discrete measure may give a better classification of industry homogeneity than a continuous measure.
} 


\section{B. Refinements to the Succession Planning Variable}

Thus far, my analysis assumes that the existence of a president/COO indicates the presence of a succession plan. It is possible, however, that in firms classified as having no heir apparent, some other executive, such as the executive VP or vice chairman, could in fact be the designated heir. I therefore refine my classification scheme using information on the compensation of the top five officers of the firm, as provided in the proxy statements. I reclassify all firm-years without a succession plan as having a plan if the second-highest paid executive in the firm (other than the CEO) is not older than the CEO, and is paid significantly more than anyone else on the management team. Since it is hard to define what is significantly more pay, I examine two cases. First, I assume that the person is heir apparent if he is not older than the CEO, and gets at least $10 \%$ more pay than the next highest-paid individual. Second, I use the same criteria, but require that he make at least $20 \%$ more pay than the next highest-paid individual. IMy measure of pay is total cash compensation (salary and bonus). The results are qualitatively similar although weaker in some specifications.

\section{Logistic Regressions of Forced and Inside Turnover}

I next examine how turnover is associated with the use of relay succession. Since the succession planning and turnover variables are endogenously determined, I estimate turnover using either a bivariate probit or a two-step procedure (Greene (1998)). The latter method gives consistent estimators but is'not efficient. Accordingly, I use bivariate probit regressions.

Table 5 reports the results. The variable TURNOVER is as defined earlier. INSIDER (OUTSIDER) takes the value of 1 for inside (outside) succession and 0 otherwise (including non-turnovers). Similarly, FORCED (VOLUNTARY) takes the value of 1 for forced (voluntary) succession and 0 otherwise. 'Firm size is the logarithm of book value of assets. Adjusted returns are returns in excess of the CRSP value-weighted index. Adjusted ROA is the ROA in excess of the two-digit SIC average. AGE64_66 (AGE66) is a dummy variable that takes the value 1 if the incumbent CEO is between 64 and 66 years (over 66 years) of age. Heir apparent takes the value 1 if the firm has relay succession. FOUNDER is a dummy variable that takes the value 1 if the CEO is the founder or a member of the founder's family. Other control variables include industry homogeneity, board size, institutional ownership, CEO ownership, and inside ownership ${ }^{8}$ Again, the marginal effects of the independent variables on turnover type are shown.

Consistent with my hypothesis, I find that having an heir apparent increases the probability of both insider and voluntary succession (columns 1 and 3 of Ta-

\footnotetext{
${ }^{8}$ Only the turnover regressions are reported. The succession planning equation in the bivariate probit is not reported as results are qualitatively similar to those in Table 4. The succession planning equation used is Model 6 in Table 4. Results are similar if Model 5 is used instead. For the turnover regression, the choice of control variables is influenced by Weisbach (1988), Yermack (1996), Denis, Denis, and Sarin (1997), Parrino (1997), and Huson et al. (2001). Also, data on institutional ownership for the years 1993-1997 were collected from Compact Disclosure. For each firm, the 1992 value of institutional ownership was used for the years 1988-1991. This approximation appears reasonable given the high correlation (greater than 0.9 ) in institutional ownership across years in my sample. The main results are similar if institutional ownership is not included in the regressions.
} 


\section{TABLE 5}

\section{Bivariate Probit Regressions: Turnover Type and Relay Succession Planning}

\begin{tabular}{|c|c|c|c|c|c|}
\hline \multirow{2}{*}{\multicolumn{6}{|c|}{$\begin{array}{l}\text { The marginal effects of the independent variables on the likelihood of turnover are repor } \\
\text { continuous variables are calculated for a unit change of that variable, holding other variable } \\
\text { effects of dummy variables are calculated for a change in the dummy from } 0 \text { to } 1 \text {, holding } \\
\text { Each of the five dependent variables is estimated as part of a bivariate probit system wher } \\
\text { is the succession planning equation (model } 6 \text { of Table } 4 \text { ). There are } 5,362 \text { observations. Turn } \\
1 \text { every time the CEO changes. Heir apparent is set equal to } 1 \text { if the firm has a president/CC } \\
\text { chairman. Insider (outsider) takes the value } 1 \text { if there is an inside (outside) turnover and } 0 \text { ot } \\
\text { defined as one where the successor has been with the firm for more than one year. Forced } \\
\text { value } 1 \text { if there is a forced (voluntary) turnover, and } 0 \text { otherwise. A turnover is classified as for } \\
\text { identifies the turnover as forced or if the CEO is under } 60 \text { years, and does not resign due } \\
\text { up a comparable position in another firm. Firm size is logarithm of assets. Adjusted returns } \\
\text { value-weighted index and adjusted ROA is ROA net of the (two-digit) industry median. Age6 } 6 \\
1 \text { if the departing CEO's age is between } 64 \text { and } 66 \text { years (over } 66 \text { years). Inside ownership is } \\
\text { directors net of CEO ownership. The industry homogeneity measure is based on Parrino (1 } \\
\text { correlation coefficient for an industry return index in a two-factor model that also includes } \\
\text { for more homogeneous industries. The industry homogeneity dummy takes the value } 1 \text { for } \\
\text { mean value of the industry homogeneity measure. Intercepts are included but not reported } \\
\text { coefficient estimates are given in parentheses and are based on robust standard errors. } \\
\text { Dependent Variable }\end{array}$}} \\
\hline & & & & & \\
\hline & Insider & Outsider & Voluntary & Forced & Turnover \\
\hline Lagged firm size & $\begin{array}{c}-0.000 \\
(0.941)\end{array}$ & $\begin{array}{c}-0.000 \\
(0.574)\end{array}$ & $\begin{array}{c}0.000 \\
(0.914)\end{array}$ & $\begin{array}{c}-0.001 \\
(0.697)\end{array}$ & $\begin{array}{c}-0.001 \\
(0.749)\end{array}$ \\
\hline Lagged adjusted returns & $\begin{array}{c}-0.010 \\
(0.474)\end{array}$ & $\begin{array}{c}-0.002 \\
(0.018)\end{array}$ & $\begin{array}{c}-0.005 \\
(0.695)\end{array}$ & $\begin{array}{c}-0.078 \\
(0.005)\end{array}$ & $\begin{array}{c}-0.035 \\
(0.040)\end{array}$ \\
\hline Change in adjusted ROA & $\begin{array}{c}-0.096 \\
(0.269)\end{array}$ & $\begin{array}{c}-0.002 \\
(0.587)\end{array}$ & $\begin{array}{c}-0.177 \\
(0.046)\end{array}$ & $\begin{array}{c}0.041 \\
(0.575)\end{array}$ & $\begin{array}{c}-0.147 \\
(0.142)\end{array}$ \\
\hline Age64_66 & $\begin{array}{c}0.213 \\
(0.002)\end{array}$ & $\begin{array}{c}0.002 \\
(0.035)\end{array}$ & $\begin{array}{c}0.270 \\
(0.000)\end{array}$ & $\begin{array}{c}0.052 \\
(0.308)\end{array}$ & $\begin{array}{c}0.272 \\
(0.000)\end{array}$ \\
\hline Age66 & $\begin{array}{c}0.134 \\
(0.000)\end{array}$ & $\begin{array}{c}0.015 \\
(0.000)\end{array}$ & $\begin{array}{c}0.211 \\
(0.000)\end{array}$ & $\begin{array}{c}-0.003 \\
(0.867)\end{array}$ & $\begin{array}{c}0.213 \\
(0.000)\end{array}$ \\
\hline CEO ownership & $\begin{array}{c}-0.006 \\
(0.002)\end{array}$ & $\begin{array}{c}-0.001 \\
(0.118)\end{array}$ & $\begin{array}{c}-0.007 \\
(0.001)\end{array}$ & $\begin{array}{c}-0.005 \\
(0.114)\end{array}$ & $\begin{array}{c}-0.009 \\
(0.000)\end{array}$ \\
\hline Inside ownership & $\begin{array}{c}0.001 \\
(0.062)\end{array}$ & $\begin{array}{c}-0.000 \\
(0.155)\end{array}$ & $\begin{array}{c}0.000 \\
(0.426)\end{array}$ & $\begin{array}{c}0.000 \\
(0.792)\end{array}$ & $\begin{array}{c}0.000 \\
(0.390)\end{array}$ \\
\hline Homogeneity dummy & $\begin{array}{c}0.012 \\
(0.427)\end{array}$ & $\begin{array}{c}-0.000 \\
(0.913)\end{array}$ & $\begin{array}{c}0.003 \\
(0.848)\end{array}$ & $\begin{array}{c}-0.007 \\
(0.608)\end{array}$ & $\begin{array}{c}0.009 \\
(0.580)\end{array}$ \\
\hline Board size & $\begin{array}{c}0.000 \\
(0.939)\end{array}$ & $\begin{array}{c}0.000 \\
(0.015)\end{array}$ & $\begin{array}{c}-0.001 \\
(0.593)\end{array}$ & $\begin{array}{c}-0.001 \\
(0.397)\end{array}$ & $\begin{array}{c}-0.001 \\
(0.357)\end{array}$ \\
\hline Founder & $\begin{array}{c}-0.036 \\
(0.034)\end{array}$ & $\begin{array}{c}-0.004 \\
(0.000)\end{array}$ & $\begin{array}{c}-0.047 \\
(0.002)\end{array}$ & $\begin{array}{c}0.006 \\
(0.742)\end{array}$ & $\begin{array}{c}-0.051 \\
(0.005)\end{array}$ \\
\hline Institutional ownership & $\begin{array}{c}-0.000 \\
(0.342)\end{array}$ & $\begin{array}{c}-0.000 \\
(0.193)\end{array}$ & $\begin{array}{c}-0.000 \\
(0.376)\end{array}$ & $\begin{array}{c}-0.000 \\
(0.122)\end{array}$ & $\begin{array}{r}-0.000 \\
(0.120)\end{array}$ \\
\hline Heir apparent & $\begin{array}{c}0.226 \\
(0.013)\end{array}$ & $\begin{array}{c}-0.001 \\
(0.230)\end{array}$ & $\begin{array}{c}0.157 \\
(0.003)\end{array}$ & $\begin{array}{c}-0.185 \\
(0.000)\end{array}$ & $\begin{array}{c}0.159 \\
(0.091)\end{array}$ \\
\hline
\end{tabular}

ble 5). These effects are significant statistically ( $p \leq 0.02$ ) and economically. The presence of a succession plan increases the likelihood of inside (voluntary) succession by $0.226(0.157)$. Also, as expected, the presence of an heir apparent decreases the probability of both outside and forced succession, although in the case of outside succession the statistical significance is weaker $(p=0.23)$. The last column of Table 5 indicates that the probability of turnover increases with the presence of an heir. This could be just capturing the fact that firms are more likely to pick an heir just before CEO turnover.

Results on control variables are generally consistent with findings in other studies. For instance, poor stock performance significantly increases the likelihood of turnover, outside succession, and forced succession. Turnover is also more likely when the incumbent CEO is over 64 years, has low ownership, or is 
not a founder. Inside ownership, institutional ownership, and board size do not appear to have a large effect on turnover type.

For completeness, I also estimate multinomial logistic regressions of turnover. Two models are estimated. In the first, the dependent variable takes the value of 0 for no turnover, 1 for inside succession, 2 for outside succession. In the second, the dependent variable takes the value of 0 for no turnover, 1 for voluntary turnover, and 2 for forced turnover. Since the bivariate probit estimation cannot be applied to the case of multinomial logit with an endogenous (binary) independent variable, I use a two-step procedure discussed in Greene (1998) to address the endogeneity of the turnover and succession planning decisions. I first estimate the succession planning equation using maximum likelihood logistic analysis. I then use the predicted value of this variable in the turnover choice equation. The use of predicted probabilities in the second step results in biased standard errors. To correct for this, I report $p$-values obtained from bootstrapping the regression coefficients. ${ }^{9}$ In unreported results, I find that the coefficient on the succession plan variable always has the right sign, but is statistically insignificant. This could be due to the two-step procedure being inefficient (Greene (1998)) relative to the bivariate probit. The economic significance of the succession planning variable is, however, high.

\section{Relay Succession and Horizon Problems}

Career concerns could serve to mitigate agency problems between managers and shareholders, but such concerns could be negligible toward the end of the CEO's tenure leading to significant agency problems (Gibbons i and Murphy (1992)). In the case of relay succession, since the CEO typically remains as the chairman of the board, this type of agency problem (termed horizon problems) may be mitigated. To check if this is true, I examine how investmient expenditures and accruals management over the CEO's tenure vary across firms that have relay succession and those that do not. The results are reported in Table 6. My experiment is in the same spirit as Dechow and Sloan (1991) who examine (in Table 7 of their paper) whether having a relay succession plan affects investment in research and development (R\&D). My dependent variables are R:\&D expenditure (R\&D), capital expenditure (CAPEX), discretionary current accruals (DCA), and discretionary long-term accruals (DLA). Accruals are as defined in Teoh, Welch, and Wong (1998). The choice of independent variables is influenced by earlier research (Bhagat and Welch (1995), Teoh et al. (1998), and Coles, Daniel, and Naveen (2006)). Regression specifications include industry and year dummy variables. Reported $p$-values are based on robust standard errors. Also, since the median R\&D investment is 0 , I use Tobit specifications for the R\&D regression. Table 6 shows that over their tenure, CEOs reduce R\&D, increase CAPEX, and have higher discretionary accruals. These effects, however, are significantly lower

\footnotetext{
${ }^{9}$ This bias can be corrected analytically, using the Murphy and Topel (1985) correction (Greene (2003), p. 509), but deriving and programming this can be a very lengthy procedure. Bootstrapping is a more straightforward alternative (Efron and Tibshirani (1993), Margolis and Simonnet (2002), p. 14).
} 
in firms that have relay succession. The results suggest that succession planning plays a role in mitigating agency problems in firms.

\section{TABLE 6}

\section{Regressions of R\&D, CAPEX, and Accruals on Heir Apparent}

The sample is drawn from the Forbes Annual Compensation Surveys and consists of 6,714 firm-years of data from 19881997 with 691 turnovers. R\&D is research and development expenditure scaled by assets. CAPEX is capital expenditure scaled by assets. DCA is discretionary current accruals scaled by beginning assets. DLA is discretionary long-term accruals scaled by beginning assets. DCA and DLA are computed based on Teoh, Welch, and Wong (1998). For R\&D, a Tobit regression is used, while other regressions use OLS. Cash is the end of year balance sheet value scaled by assets. Market-to-book ratio is market value of assets divided by book value of assets. Tenure is the number of years the CEO has been in office. Heir apparent is classified as 1 if the firm has a president/COO who is not older than the chairman or CEO. Firm size is the log of assets. Leverage is total book debt divided by book value of assets. Intercepts are included but not reported. $p$-values are given in parentheses and are based on robust standard errors.

Dependent Variable

\begin{tabular}{|c|c|c|c|c|}
\hline \multirow{2}{*}{ Independent Variables } & \\
\hline & R\&D & CAPEX & DCA & DLA \\
\hline Cash & $\begin{array}{c}7.649 \\
(0.000)\end{array}$ & $\begin{array}{c}-5.891 \\
(0.000)\end{array}$ & $\begin{array}{r}-0.082 \\
(0.000)\end{array}$ & $\begin{array}{c}-0.165 \\
(0.000)\end{array}$ \\
\hline Market-to-book ratio & $\begin{array}{c}1.242 \\
(0.000)\end{array}$ & $\begin{array}{c}0.169 \\
(0.239)\end{array}$ & $\begin{array}{c}0.004 \\
(0.179)\end{array}$ & $\begin{array}{c}0.000 \\
(0.908)\end{array}$ \\
\hline Tenure $\left(b_{1}\right)$ & $\begin{array}{r}-0.060 \\
(0.000)\end{array}$ & $\begin{array}{c}0.040 \\
(0.000)\end{array}$ & $\begin{array}{c}0.001 \\
(0.163)\end{array}$ & $\begin{array}{c}0.001 \\
(0.000)\end{array}$ \\
\hline Tenure*Heir apparent $\left(b_{2}\right)$ & $\begin{array}{c}0.033 \\
(0.089)\end{array}$ & $\begin{array}{r}-0.036 \\
(0.006)\end{array}$ & $\begin{array}{c}-0.001 \\
(0.370)\end{array}$ & $\begin{array}{c}-0.001 \\
(0.046)\end{array}$ \\
\hline Heir apparent & $\begin{array}{r}-0.071 \\
(0.747)\end{array}$ & $\begin{array}{c}0.342 \\
(0.008)\end{array}$ & $\begin{array}{c}0.004 \\
(0.444)\end{array}$ & $\begin{array}{c}0.001 \\
(0.837)\end{array}$ \\
\hline Firm size & $\begin{array}{c}0.756 \\
(0.000)\end{array}$ & $\begin{array}{r}-0.081 \\
(0.111)\end{array}$ & $\begin{array}{r}-0.001 \\
(0.645)\end{array}$ & $\begin{array}{r}-0.006 \\
(0.009)\end{array}$ \\
\hline Leverage & $\begin{array}{r}-7.666 \\
(0.000)\end{array}$ & $\begin{array}{c}-0.201 \\
(0.734)\end{array}$ & $\begin{array}{r}-0.012 \\
(0.468)\end{array}$ & $\begin{array}{r}-0.039 \\
(0.003)\end{array}$ \\
\hline Stock return & $\begin{array}{c}-1.353 \\
(0.000)\end{array}$ & $\begin{array}{c}-0.377 \\
(0.146)\end{array}$ & $\begin{array}{r}-0.018 \\
(0.180)\end{array}$ & $\begin{array}{r}-0.013 \\
(0.040)\end{array}$ \\
\hline ROA & $\begin{array}{c}-5.008 \\
(0.000)\end{array}$ & $\begin{array}{l}15.350 \\
(0.000)\end{array}$ & $\begin{array}{c}0.012 \\
(0.745)\end{array}$ & $\begin{array}{c}0.053 \\
(0.191)\end{array}$ \\
\hline $\begin{array}{l}\text { Year dummies } \\
\text { Two-digit industry dummies } \\
p \text {-value for } F \text {-test of } b_{1}+b_{2}=0\end{array}$ & $\begin{array}{r}\text { Yes } \\
\text { Yes } \\
0.058\end{array}$ & $\begin{array}{r}\text { Yes } \\
\text { Yes } \\
0.649\end{array}$ & $\begin{array}{r}\text { Yes } \\
\text { Yes } \\
0.191\end{array}$ & $\begin{array}{r}\text { Yes } \\
\text { Yes } \\
0.059\end{array}$ \\
\hline No. of obs. & 6,144 & 6,052 & 4,318 & 5,026 \\
\hline
\end{tabular}

\section{E. Logistic Regression Model to Predict when the Heir Apparent Will Take Over}

If the proxy used for heir apparent is correct and if firms designate an heir apparent to minimize succession costs, then, whenever an heir is present before succession, this person should become the new CEO. I estimate a logistic model using the sample of firm-years that have an heir apparent before turnover ( 422 observations) to predict when the heir will take over as CEO (in 399 of these cases, the heir became the CEO). The dependent variable is BECOME CEO, which takes the value 1 if the heir apparent becomes the CEO and 0 otherwise. Marginal effects and $p$-values are presented in Table 7. I find that only firm size and adjusted returns are significant in explaining whether the heir becomes the CEO. This is consistent with Vancil (1987) who suggests that the heir is evaluated during the grooming period, and is elevated to CEO if his performance is deemed satisfactory. The heir apparent and the incumbent CEO appear to be held jointly responsible for the firm's performance. The marginal effects on other variables 
generally have the expected signs, but lack statistical significance. The probability that the heir succeeds is lower for forced turnovers and in more homogenous industries. The probability increases with the age of the heir, but at a declining rate. The lack of power in these results could be due to the overall high probability that the heir becomes the CEO.

\section{TABLE 7}

\section{Determinants of Heir Apparent's Appointment to CEO}

\begin{tabular}{|c|c|c|c|c|}
\hline \multicolumn{5}{|c|}{$\begin{array}{l}\text { The sample is drawn from the Forbes Annual Compensation Surveys from } 1988-1997 \text { with a total of } 6 \\
\text { regressions are estimated on a subsample of } 475 \text { turnovers where there was an heir apparent present } \\
\text { turnover. The dependent variable takes the value } 1 \text { if the heir apparent becomes the CEO and takes the } \\
\text { Heir apparent is classified as } 1 \text { if the firm has a president/COO who is not older than the chairman or } C \\
\text { variables include lagged firm size (log of assets), lagged adjusted returns, industry homogeneity pr } \\
\text { index, age of the heir apparent, and the square of the age of the heir apparent. Adjusted returns are } \\
\text { CRSP value-weighted index. The industry homogeneity measure is based on the methodology of Parr } \\
\text { calculated as the mean partial correlation coefficient for an industry return index in a two-factor model } \\
\text { the market index. It is larger for more homogeneous industries. The industry homogeneity dummy tak } \\
\text { industries that are above the mean value of the industry homogeneity measure. The Herfindahl index|e } \\
\text { segment firms and is less than } 1 \text { otherwise. p-values for significance of coefficient estimates are given |n } \\
\text { are based on robust standard errors. } \\
\text { Dependent Variable }=1 \text { if Heir } \\
\text { Apparent Becomes CEO }\end{array}$} \\
\hline Firm size & $\begin{array}{r}0.017 \\
(0.03)\end{array}$ & $\begin{array}{c}0.023 \\
(0.05)\end{array}$ & & $\begin{array}{c}0.023 \\
(0.04)\end{array}$ \\
\hline Adjusted returns & $\begin{array}{c}0.067 \\
(0.09)\end{array}$ & $\begin{array}{c}0.075 \\
(0.11)\end{array}$ & & $\begin{array}{c}0.072 \\
(0.10)\end{array}$ \\
\hline Industry homogeneity measure & & $\begin{array}{c}0.102 \\
(0.61)\end{array}$ & & \\
\hline Industry homogeneity dummy & & & & $\begin{array}{c}-0.045 \\
(0.35)\end{array}$ \\
\hline Herfindahl index & & $\begin{array}{r}-0.011 \\
(0.82)\end{array}$ & 1 & $\begin{array}{r}-0.010 \\
(0.34)\end{array}$ \\
\hline Heir apparent age & $\begin{array}{r}0.024 \\
(0.44)\end{array}$ & $\begin{array}{c}0.043 \\
(0.33)\end{array}$ & I & $\begin{array}{c}0.039 \\
(0.32)\end{array}$ \\
\hline Square of heir apparent age & $\begin{array}{r}-0.000 \\
(0.48)\end{array}$ & $\begin{array}{r}-0.000 \\
(0.38)\end{array}$ & i & $\begin{array}{r}-0.000 \\
(0.37)\end{array}$ \\
\hline Forced turnover & $\begin{array}{r}-0.227 \\
(0.00)\end{array}$ & $\begin{array}{r}-0.097 \\
(0.21)\end{array}$ & 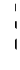 & $\begin{array}{c}-0.093 \\
(0.22)\end{array}$ \\
\hline Year dummy variables & Yes & Yes & & Yes \\
\hline
\end{tabular}

\section{Discussion of Alternative Interpretations}

In this section, I discuss other possible interpretations of the results, including managerial entrenchment. I also explore the robustness of the results to other specifications.

\section{A. Alternative Definition of Succession Planning}

In the discussions so far, I treat a firm-year as having a succession plan if the firm has an heir apparent. Different firms, however, could be in different phases of the succession process. This could result in a firm being classified as not having a succession plan in a particular year, even if the firm in general has one.iTo address this, I redefine a firm as having a succession plan over the sample period if it has a succession plan in any of the individual years. My main inferences remain. 
One difference is that the coefficient on the succession planning variable is now statistically insignificant in the regressions of voluntary turnover and turnover.

\section{B. Does Split Leadership Facilitate Grooming or Reflect Optimal Governance?}

The fact that more complex firms have a president distinct from the CEO may not, in fact, be related to relay succession planning. It may merely indicate that a split leadership structure (president different from the CEO) is optimal for such firms; two individuals may be better equipped than a single individual to deal with the range of issues confronting the firm. The evidence, however, is not consistent with the latter interpretation.

First, if firms split the positions of CEO and president merely to aid in management and not to facilitate succession planning, then I should see that the positions are permanently split, and not merely split in advance of CEO turnover. A casual look at some of the announcements of president appointments ${ }^{10}$ indicates that promotion to president is to facilitate a smooth transition from one CEO to the next. Figure 1 indicates a definite pattern: the heir apparent position gets filled as CEO turnover approaches. The regressions predicting succession planning in Table 4 reflect this pattern; the coefficient of the age dummy is strongly significant, indicating that an heir is typically appointed as the CEO approaches retirement.

Second, of the firms classified as having relay succession, only about $15 \%$ have a president every year. This suggests that the splitting of the CEO and president positions is done to manage succession planning and not to split the responsibilities of managing the firm. Third, I repeat the results in Tables 4 and 5 without the succession planning variable, but with an indicator variable that takes the value 1 if the firm has a president/COO in some, but not all years (temporarily split leadership). If the optimal leadership argument is correct, excluding observations with permanently split leadership should yield substantially different results. My main inferences, however, are qualitatively similar, although marginally weaker in a couple of specifications. Overall, my results appear more supportive of the grooming theory. Both grooming and optimal governance arguments may be correct, however, and it is hard to fully disentangle the two.

\section{Could Entrenchment Be Driving the Results?}

It is possible that the incumbent CEO may try to entrench himself by failing to appoint a successor in the hope that the absence of an heir apparent will discourage the board from firing him (Rajan and Wulf (2004)). On the other hand, succession planning could be used by the incumbent $\mathrm{CEO}$ to entrench himself. A hand-picked successor may be more likely to support the incumbent CEO's policies and may also allow the incumbent $\mathrm{CEO}$ to serve on the board of directors after he retires. In this subsection, I examine which of these two views is best supported by the data. I find that incumbent CEOs in firms with succession plans have longer tenures as CEOs and are more likely to retain board positions after retirement. Also, both forced and outside turnover are significantly less sensitive

\footnotetext{
${ }^{10}$ Reported in the Appendix, which is available from the author.
} 
to performance in firms that have succession plans. Moreover, turnover (forced, voluntary, outside, and inside) is not sensitive to performance in firms with succession plans. While these findings support the notion that succession planning is associated with managerial entrenchment, they are also consistent with the notion that firms with relay succession place a higher value on firm-specific human capital. Further, the lower sensitivity of forced and outside turnover in firms with succession plans could be due to the higher succession costs in these' firms. Three other findings are inconsistent with the concept of managerial entrenchment being associated with succession planning. First, as stated earlier, $I_{1}^{\prime}$ find that the market-to-book ratio is not different for firms with and without succession plans. Second, the stock market performance of the firm appears to matter in determining whether the heir apparent will be nominated as CEO. Finally, the abnormal returns on announcement of the appointment of the heir apparent are significantly positive. Overall, my findings provide little evidence of an association between managerial entrenchment and succession planning.

\section{Relay Succession versus Horse Race Succession}

While the main focus of this study is to understand relay succession, it is interesting to examine the kinds of firms that do horse race succession. This analysis, however, is not without its limitations. First, as defined here, a horse race succession is one in which a number of candidates compete for the CEO post. In reality, firms that have relay successions in which an overt heir apparent is appointed could also have a horse race for the position of president. So the two categories are not mutually exclusive; firms employing relay succession are just having the horse race earlier in the succession process and earlier in the career of the manager.

Second, unlike relay succession, it is rarely clear whether a given firm has a horse race succession policy or some other succession policy. For instance, consider a firm that has below the rank of CEO three VPs but no president. This firm either could have already designated one of these three VPs as the next CEO (which is apparent to people within the firm, but typically not to researchers), the firm could be having a horse race among the three VPs for the position of CEO, or the firm may not be considering succession planning at all. With these caveats, I examine if there are differences in characteristics between firms that use relay and firms that use horse race successions using the sample of 691 turnovers. For this sample of firms, I classify as horse race succession all succession s where the CEO was formerly an executive VP, senior VP, or VP. In unreported results, I compare the three groups of firms (firms with horse race succession! firms with relay succession, and all others) and find that firms with relay succession tend to be larger, more diversified, and in less homogeneous industries relative to firms with horse race succession. Further, firms with horse race and those with other kinds of succession plans are more similar to each other in terms of the Herfindahl index and the homogeneity measure. These results provide further evidence that relay succession planning is adopted by more complex firms. ${ }^{11}$

\footnotetext{
${ }^{11} \mathrm{GE}$, of course, is one exception to this argument. GE is a large, complex, highly diversified firm that follows a horse race succession. In GE's case, this is partly due to tradition, as per Jack Welch. An
} 


\section{E. Announcement Period Abnormal Performance}

Numerous studies examine abnormal returns around announcement of CEO turnover with largely different results. ${ }^{12}$ For the sample of observations for which turnover announcement dates are available, the CAAR is $0.82 \%(p \leq 0.01)$, consistent with earlier studies (Huson et al. (2001)). The CAAR is lower for firms with relay succession relative to those without $(0.41 \%$ versus $1.45 \%)$, consistent with the succession announcement being a non-event for these firms. The difference is significant ( $p \leq 0.01$ ). The CAAR on announcement of the appointment of an heir apparent is $0.41 \%(p \leq 0.01)$, consistent with the appointment being in shareholder interests.

\section{F. Changes in Operating Performance around CEO Turnover}

If firms choose to have a relay succession plan based on expected succession costs, then relay succession by itself should not predict future changes in performance. I examine this issue by studying ROA changes around CEO turnover for my sample of successions to see if there is any difference in operating performance between firms with and without an heir apparent. I regress changes in ROA on the type of turnover, firm size, lagged ROA, announcement period abnormal returns, and the heir apparent variable, and find that performance improvements are not different for firms with and without relay succession.

\section{Conclusions}

Most studies on CEO turnover to date focus on the individual components of CEO transition, such as the determinants of CEO turnover and the determinants of inside versus outside succession. This study examines how each of these components is part of a larger process guiding CEO succession in firms. I document that a significant fraction of my sample firms uses the relay succession process as hypothesized in Vancil (1987). I argue that firm size, degree of diversification, and industry structure are correlated with operational complexity and with the costs of transferring firm-specific knowledge and expertise. Therefore, these measures should reflect a firm's propensity to use a relay succession process. Consistent with this, I find that larger firms, more diversified firms, and firms in heterogeneous industries are more likely to use relay succession.

I find no compelling evidence that succession planning is associated with entrenchment; instead having a succession plan appears to help mitigate horizon problems. Also, there is a significantly positive share price reaction when firms announce the appointment of the heir apparent, and Tobin's $Q$ is similar

important factor also is that in the case of GE, the management is exposed to all the different aspects of the firm as part of their training. For example, Jeffrey Immelt, GE's new CEO, was on the board of GE Capital for many years. He also had nearly 20 years of experience in corporate marketing in GE plastics, GE appliances, and GE medical systems at the time he was nominated CEO.

${ }^{12}$ For more details, refer to Reinganum (1985), Warner et al. (1988), Weisbach (1988), Furtado and Rozeff (1987), Bonnier and Bruner (1989), and Furtado (1985). The conflicting findings could be due to the inability of these studies to fully capture market expectations before the turnover announcement (Warner et al. (1988), Jensen and Warner (1988)). 
for firms both with and without relay succession. I examine various alternative explanations for my results; collectively, the results suggest that firms appear to optimally manage the succession process. I cannot infer that all firms should do relay succession planning or that relay succession is good for all firms. The evidence is merely consistent with relay succession being undertaken by firms that most stand to benefit from it.

An interesting area for future research is to examine horse race successions in more detail. Horse race successions typically are associated with more uncertainty regarding the future $\mathrm{CEO}$. Also, once the future $\mathrm{CEO}$ is announced, the unsuccessful candidates for the $\mathrm{CEO}$ post typically resign (recent events at GE exemplify these issues) leading to high turnover at the top management level in horse race successions. Although this paper attempts to provide an understanding of characteristics of firms that use relay and horse race successions, there are many interesting issues left to explore.

\section{References}

Agrawal, A.; C. Knoeber; and T. Tsoulouhas. "Are Outsiders Handicapped in CEO Successions?" Journal of Corporate Finance, forthcoming (2006).

Baliga, B.; R. Moyer; and R. Rao. "CEO Duality and Firm Performance: What's the Fuss?" Strategic Management Journal, 17 (1996), 41-53.

Becker, G. Human Capital. Chicago, IL: Univ. of Chicago Press (1964).

Bhagat, S., and I. Welch. "Corporate Research and Development Investments: International Comparisons." Journal of Accounting and Economics, 19 (1995), 443-470.

Bonnier, K., and R. Bruner. "An Analysis of Stock Price Reaction to Management Change in Distressed Firms." Journal of Accounting and Economics, 11 (1989), 95-106.

Borokhovich, K.; R. Parrino; and T. Trapani. "Outside Directors and CEO Selection." Journal of Financial and Quantitative Analysis, 31 (1996), 337-355.

Brickley, J.; J. Coles; and G. Jarrell. "Leadership Structure: Separating the CEO and Chairman of the Board." Journal of Corporate Finance, 3 (1997), 189-220.

Brickley, J.; J. Coles; and J. Linck. "What Happens to CEOs After they Retire? Evidence on Career Concerns and CEO Incentives." Journal of Financial Economics, 52 (1999), 341-377.

Cannella, A., Jr., and M. Lubatkin. "Succession as a Sociopolitical Process: Internal Impediments to Outsider Selection." Academy of Management Journal, 36 (1993), 763-793.

Carmichael, L. "Firm-Specific Human Capital and Promotion Ladders." Bell Journal of Economics, 14 (1983), 251-258.

Chan, W. "External Recruitment versus Internal Promotion." Journal of Labor Economics, 14 (1996), $555-570$

Coles, J.; N. Daniel; and L. Naveen. "Managerial Incentives and Risk-Taking." Journal of Financial Economics, 79 (2006), 431-468.

Dechow, P., and R. Sloan. "Executive Incentives and the Horizon Problem." Journal of Accounting and Economics, 14 (1991), 51-89.

Denis, D.; D. Denis; and A. Sarin. "Ownership Structure and Top Executive Turnover." Journal of Financial Economics, 45 (1997), 193-221.

Efron, B., and R. J. Tibshirani. An Introduction to the Bootstrap: Monographs on Statistics and Applied Probability, vol. 57. New York, NY: Chapman and Hall (1993).

Finkelstein, S., and D. Hambrick. "Chief Executive Compensation: A Study of the Intersection of Markets and Political Processes." Strategic Management Journal, 10 (1989), 12134.

Furtado, E. "Changes in Senior Management and Their Effects on Stockholder Value.." Unpubl. PhD Diss. (1985).

Furtado, E., and M. Rozeff. "The Wealth Effects of Company Initiated Management Changes." Journal of Financial Economics, 18 (1987), 147-160.

Gibbons, R., and K. Murphy. "Optimal Incentive Contracts in the Presence of Career Concerns: Theory and Evidence." Journal of Political Economy, 100 (1992), 468-505.

Greene, W. H. "Gender Economics Courses in Liberal Arts Colleges: Further Results." Journal of Economic Education, 29 (1998), 291-300.

Greene, W. H. Econometric Analysis, 5th ed. Upper Saddle River, NJ: Prentice Hall (2003). 
Himmelberg, C., and G. Hubbard. "Incentive Pay and the Market for CEOs: An Analysis of Pay-forPerformance Sensitivity." Working Paper, Columbia Univ. (2000).

Hirshleifer, D., and I. Welch. "An Economic Approach to the Psychology of Change: Amnesia, Inertia and Impulsiveness." Journal of Economics and Management Strategy, 11 (2002), 379-421.

Huson, M.; R. Parrino; and L. Starks. "Internal Monitoring Mechanisms and CEO Turnover: A Long Term Perspective." Journal of Finance, 56 (2001), 2265-2297.

Jaggia, P., and A. Thakor. "Firm-Specific Human Capital and Optimal Capital Structure." International Economic Review, 35 (1994), 283-308.

Jensen, M., and J. Warner. "The Distribution of Power among Corporate Managers, Shareholders and Directors." Journal of Financial Economics, 20 (1988), 3-24.

Lazear, E., and S. Rosen. "Rank-Order Tournaments as Optimum Labor Contracts." Journal of Political Economy, 89 (1981), 841-864.

Margolis, D. N., and V. Simonnet. "Technical/Professional versus General Education, Labor Market Networks and Labor Market Outcomes." Working Paper, Université Paris (2002).

McConnell, J., and H. Servaes. "Additional Evidence on Equity Ownership and Corporate Value." Journal of Financial Economics, 27 (1990), 595-612.

Morck, R.; A. Shleifer; and R. Vishny. "Management Ownership and Market Valuation." Journal of Financial Economics, 20 (1988), 293-315.

Murphy, K., and J. Zimmerman. "Financial Performance Following CEO Turnover." Journal of Accounting and Economics, 16 (1993), 273-315.

Murphy, K., M., and R. H. Topel. "Estimation and Inference in Two-Step Econometric Models." Journal of Business and Economic Statistics, 3 (1985), 370-379.

Parrino, R. "CEO Turnover and Outside Succession: A Cross-Sectional Analysis." Journal of Financial Economics, 46 (1997), 165-197.

Rajan, R., and J. Wulf. "The Flattening of the Firm: Evidence on the Changing Nature of Firm Hierarchies from Panel Data." Working Paper, NBER (2004).

Reinganum, M. "The Effect of Executive Succession on Stockholder Wealth." Administrative Science Quarterly, 30 (1985), 46-60.

Rose, N., and A. Shepard. "Firm Diversification and CEO Compensation: Managerial Ability or Executive Entrenchment?" RAND Journal of Economics, 28 (1997), 489-514.

Teoh, S.; I. Welch; and T. J. Wong. "Earnings Management and the Long-Run Market Performance of Initial Public Offerings." Journal of Finance, 53 (1998), 1935-1974.

Vancil, R. "Passing the Baton: Managing the Process of CEO Succession." Boston, MA: Harvard Business School Press (1987).

Warner, J.; R. Watts; K. Wruck. "Stock Prices and Top Management Changes." Journal of Financial Economics, 20 (1988), 461-492.

Weisbach, M. "Outside Directors and CEO Turnover." Journal of Financial Economics, 20 (1988), $431-460$.

Yermack, D. "Higher Market Valuation for Companies with a Smaller Board of Directors." Journal of Financial Economics, 40 (1996), 185-212. 
Copyright of Journal of Financial \& Quantitative Analysis is the property of Journal of Financial \& Quantitative Analysis and its content may not be copied or emailed to multiple sites or posted to a listserv without the copyright holder's express written permission. However, users may print. download, or email articles for individual use. 